\title{
Immunological effects of Kefir produced from Kefir grains versus starter cultures when fed to mice
}

\author{
Funda Davras, Zeynep Banu Guzel-Seydim, Tugba Kok Tas*
}

Suleyman Demirel University Faculty of Engineering Department of Food Engineering, Isparta 32260, Turkey

Corresponding author: Tugba Kok Tas, PhD, Assoc. Prof., Suleyman Demirel University, Faculty of Engineering, Department of Food Engineering, Isparta 32260, Turkey

Submission Date: July $3^{\text {rd }}$, 2018, Acceptance Date: August $28^{\text {th }}$, 2018, Publication Date: August $30^{\text {th }}, 2018$

Citation: Davras F., Guzel-Seydim Z.B., Kok Tas T. Immunological effects of Kefir produced from Kefir grains versus starter cultures when fed to mice. Functional Foods in Health and Disease 2018; 8(8): 412-423. DOI: https://doi.org/10.31989/ffhd.v8i8.533

\begin{abstract}
Background: Natural kefir grains have a unique microbiota. The structure contains lactic acid bacteria (LAB), acetic acid bacteria and yeast in specific ratios in a polysaccharide matrix. Authentic kefir is produced by a traditional method using kefir grains cultured in milk. In contrast, starter cultures are used instead of kefir grains in the industry. The commercial kefir starter cultures used are limited and often very different from the kefir grain microbiota. The resultant commercial "kefir" is just a fermented drink containing some probiotic microorganisms and does not possess the same microbial population or chemical and physical characteristics of authentic kefir. The aim of this project was to determine and compare the effects on the mouse immune system of kefir produced using natural kefir grain versus commercial kefir produced by starter culture.
\end{abstract}

Methods: Kefir produced with different cultures was fed to Balb/c mice (6-8 weeks, 20-25 grams, male) by gavage for two weeks at $300 \mu \mathrm{l} /$ day. Intestinal tissues were collected from sacrificed mice at the end of the trial. The control group of mice (CNI group) were fed with phosphate buffered saline (PBS). The experimental treatments were mice fed mice fed authentic kefir produced using kefir grains (KGI group) and mice fed kefir produced using starter culture (STI group). Immunoglobulin (Ig) A, Immunoglubulin G, Interleukin (IL)-4, Interleukin-10, Interleukin-12, Toll Like Receptor (TLR)-4 were analyzed immunologically in intestinal fluid samples.

Results: Results indicated that IgA values were $60.87,72.78$ and $55.31 \mathrm{ng} / \mathrm{mL}$; IgG values were 26.59, 38.90 and $29.44 \mathrm{ng} / \mathrm{mL}$; IL-4 values were 84, 40.28 and $53.28 \mathrm{pg} / \mathrm{mL}$; IL-10 values were 
$110.98,175.91$ and $134.77 \mathrm{pg} / \mathrm{mL}$; IL-12 values were 53.90, 22.93 and $24.75 \mathrm{pg} / \mathrm{mL}$; TLR-4 values were $0.53,0.43$ and $1.37 \mathrm{ng} / \mathrm{mL}$, for the CNI, KGI and STI groups, respectively.

Conclusion: The high probiotic content of grain kefir had the ability to modulate many immunological mechanisms.

Keywords: immune system, in vivo, kefir grain, probiotic, starter kefir culture

\section{BACKGROUND}

Kefir grains are small, white, gelatinous particles comprised of a primarily polysaccharide matrix in which a wide variety lactic acid bacteria (LAB), acetic acid bacteria and yeast symbiotically coexist. The water soluble polysaccharide kefiran is found in kefir grains and has antimicrobial, antiinflammatory and immune modulatory activities. Authentic kefir, produced using kefir grains, is a natural probiotic-containing fermented drink which is composed of organic acids such as lactic acid, formic acid, succinic acid, acetic acid and propionic acid, and aromatic compounds such as acetaldehyde, ethanol, acetone and diacetyl. It also contains vitamins, minerals and essential amino. As authentic kefir contains all the nutrients of milk including protein, fat and carbohydrates, it is a nutritious product. Moreover, digestion of authentic kefir is reported to be is easeir than milk due to the high enzymatic activity imparted via the kefir microbiota. Formation of fermentation metabolites by the kefir microbiota increases the nutritive value and provides better absorption in the body [1,2,3]. Authentic kefir contains L. kefiranofaciens subsp. kefiranofaciens [4], L. kefiri [5], L. acidophilus [4], L. casei [9], L. rhamnosus [6], L. plantarum [7], L. fermentum [6], L. cremoris [8], Streptococcus thermophilus [4], Bifidobacterium bifidum [4], Kluyveromyces marxianus [9], Saccharomyces cerevisiae [10] having the probiotic characteristic.

In industrial kefir production, a kefir starter culture is typically used rather than kefir grains. Kefir starter cultures contain a limited number of bacteria and yeast. L. kefiranofaciens subsp. kefiranofaciens, L. kefiranofaciens subsp. kefirgranum, L. kefiri and L. parakefiri bacteria, which are the characteristic species in kefir grains, are not found in commercial kefir starter cultures.

It has been reported that authentic kefir has positive effects on health such as anti-carcinogenic and anti-mutagenic effects [11,12], effects on immune system [13], anti-allergic effects [14], cholesterol-lowering effects [15], blood sugar regulating effects [16], antimicrobial and antifungal effects [17], lactose intolerance-reducing effects [18], effects on blood sugar [19], effects on the digestive system [20], effects against renal failure [21] and positive effects on dental health [22]. Milk kefir and soya milk kefir made from kefir grains as well as kefiran inhibit tumor growth in 180 tumor cells sarcoma-inoculated mice when orally consumed [23]. In a study on breast cancer involving the immune cells associated with milk glands, tumor cells were injected into Balb/c mice that were then fed with milk fermented by the lactic acid bacterial strain Lactobacillus helveticus R389. Results indicated an increase in IL-10 and a decrease in IL-6 in mice fed with L. helveticus R389 compared to the control group [24].

In studies on mice fed L. acidophilus, L. casei, L. kefiranofaciens and L.kefiri or with authentic kefir, increases in IgA [25,26] and IgG [27] were observed when compared to control mice. 
Moreover, similar studies indicated increases in the levels of IL-4, IFN (interferon) and IL-10 [2730] and a significant decrease in the levels of IL-6, IL-8 [31], IL-23, IFN- $\gamma$ [26].

The aim of the present study was to compare the effects of authentic kefir produced using kefir grains with high natural probiotic content versus kefir produced using starter culture on the immune system.

\section{METHODS}

\section{Kefir Production}

Kefir grains were obtained from Danem Co. (Suleyman Demirel University, Technopark, Isparta, Turkey). Kefir starter cultures were obtained from CHR Hansen (Istanbul, Turkey). Fresh, whole milk (3.25\% fat, $8.1 \%$ milk solids not fat) was pasteurized $\left(72^{\circ} \mathrm{C}\right.$ for 15 minutes) and then cooled to $25^{\circ} \mathrm{C}$. Milk was inoculated at a rate of $2 \%$ kefir grain for authentic kefir and $2 \%$ starter culture for commercial kefir. The inoculated milk was incubated at $25^{\circ} \mathrm{C}$ and the fermentation was stopped when the $\mathrm{pH}$ reached 4.6. Kefir grains were removed by aseptically sieving the product. Both authentic and commercial kefir samples were stored at $4{ }^{\circ} \mathrm{C}$. Kefir samples were prepared every day for gavaging mice. The microbial content of each kefir sample was measured.

\section{Animal Maintenance and Experimental Feeding Procedures}

Male BALB/c mice (6-8 week-old) weighing 20-25 g were obtained from Akdeniz University (Antalya, Turkey). The mice were kept in a room with a $12 \mathrm{~h}$ light dark cycle. The temperature was kept at $24{ }^{\circ} \mathrm{C}$, and the rats were given ad libitum access to food and water. BALB/c mice were divided into three groups of ten as control group (CKI), kefir grain group (GKI) and starter culture group (SKI). The control group (CNI) were gavaged with $300 \mu \mathrm{l} / \mathrm{d}$ PBS (phosphate buffered saline) daily for two weeks.

\section{Immunological Analyses}

Animals were fed in a way that all groups were sacrificed on the same day. Small Intestinal tissue samples of were collected by dissection, and subsequently washed with sterile PBS using Vinderola [27]. Intestinal tissues from the control group were labeled CNI, from the group fed with kefir produced from kefir grains were labeled as KGI, and from the group fed with kefir produced from starter cultures were labeled STI. All intestinal tissue samples were processed in a tissue disruptor (Janke and Kunkel Ultraturrax T-25, Germany). Samples were centrifuged at $10.000 \mathrm{xg}$ for 10 minutes at $4^{\circ} \mathrm{C}$, and the resulting supernatant was removed and stored at $-80^{\circ} \mathrm{C}$ until later thawed for analysis.

Immunological analyses were performed using BioTek Synergy HT (Winooski, VT) according to the procedures of Elabscience Mouse IgA, IgG, IL-4, IL-10, IL12 and TLR-4 Enzyme Linked ImmunoSorbent Assay (ELISA) kits (Elabscience Biotechnology Co., Houston, TX).

\section{Statistical Analyses}

All statistical analyses were performed using the IBM SPSS v. 23.0 (Statistical Packages for Social Sciences) computer software. One-way ANOVA test was used in parametric conditions and 
Kruskal Wallis test was used in non-parametric conditions in the difference analysis between groups. Values were considered significantly different when $\mathrm{p}<0.05$.

\section{RESULTS}

\section{Microbiological contents of kefir samples}

The Lactobacillus spp. contents of kefir produced using natural kefir grains was $10.54 \mathrm{log} \mathrm{cfu} / \mathrm{mL}$ for the kefir produced using kefir grains and $8.40 \log \mathrm{cfu} / \mathrm{mL}$ for the kefir produced using starter culture. The mean total yeast content of kefir produced from natural kefir grain was $5.69 \log$ $\mathrm{cfu} / \mathrm{mL}$ whereas it as $2.5 \mathrm{log} \mathrm{cfu} / \mathrm{mL}$ in starter culture kefir. L. acidophilus content of the kefir produced using kefir grain and using starter culture were 9.55, and $8.65 \log \mathrm{cfu} / \mathrm{mL}$, respectively. The Bifidobacterium spp. content of the kefir produced using kefir grain and using starter culture were 7.83 and $0.12 \log \mathrm{cfu} / \mathrm{mL}$, respectively.

Results indicated the IgA values were statistically higher in the KGI group than in the CNI and STI group (P <0.05). The IgA values in CNI, KGI and STI samples were 60.87, 72.78 and $55.31 \mathrm{ng} / \mathrm{mL}$, respectively (Figure 1).

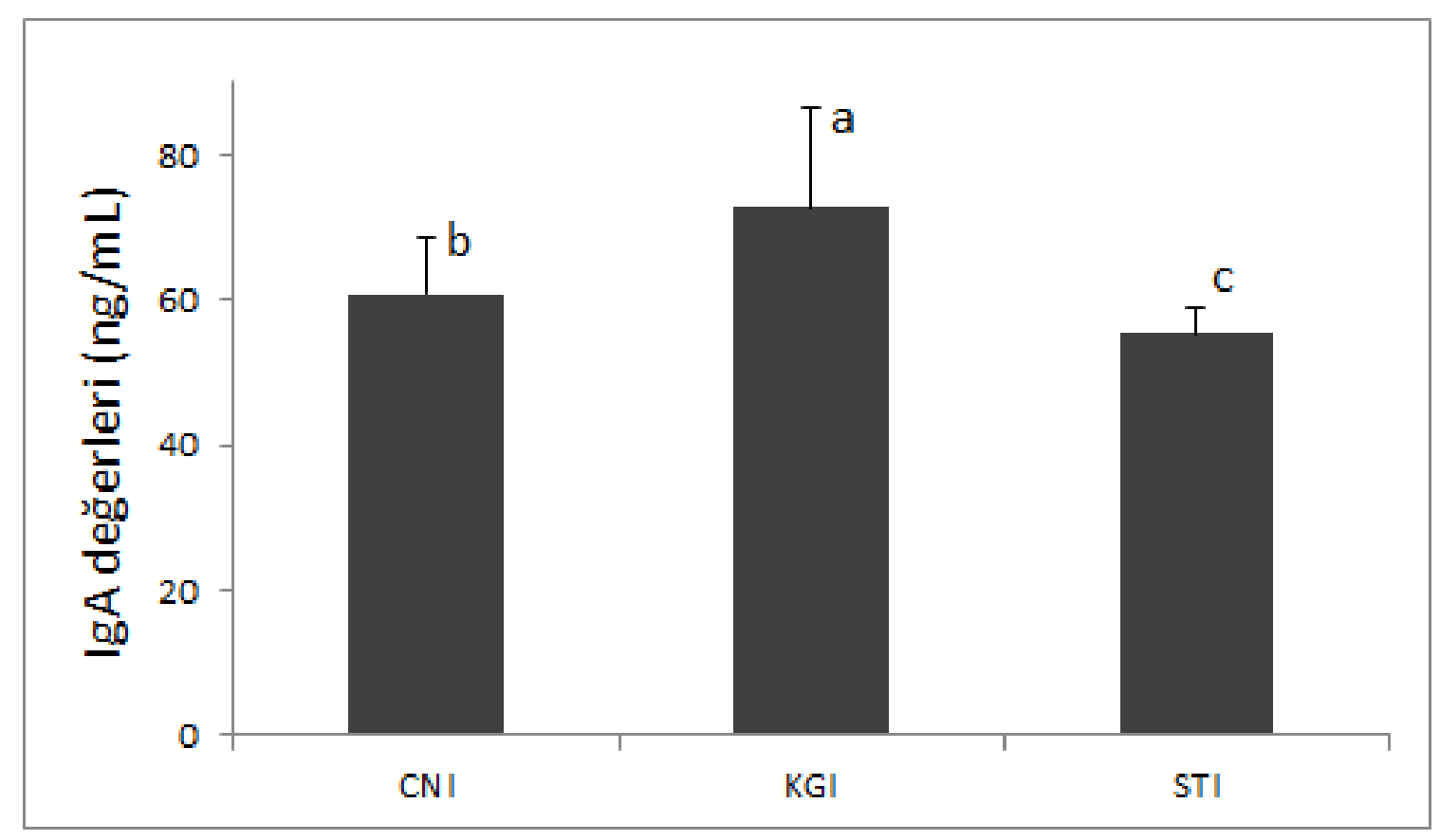

a,b,c Different letters indicate results were statistically different $(\mathrm{P}<0.05)$

Figure 1. IgA values of CNI, KGI and STI groups

Results indicated the IgG values in the KGI group were higher than those in the STI and CNI groups ( $\mathrm{P}<0.05$ ). In the CNI, KGI and STI samples, IgG values were 26.59, 38.90 and 29.44 $\mathrm{ng} / \mathrm{mL}$, respectively (Figure 2). For the $\mathrm{IgG}$ results, it was determined that there was a significant difference in all samples $(\mathrm{P}<0.05)$. 


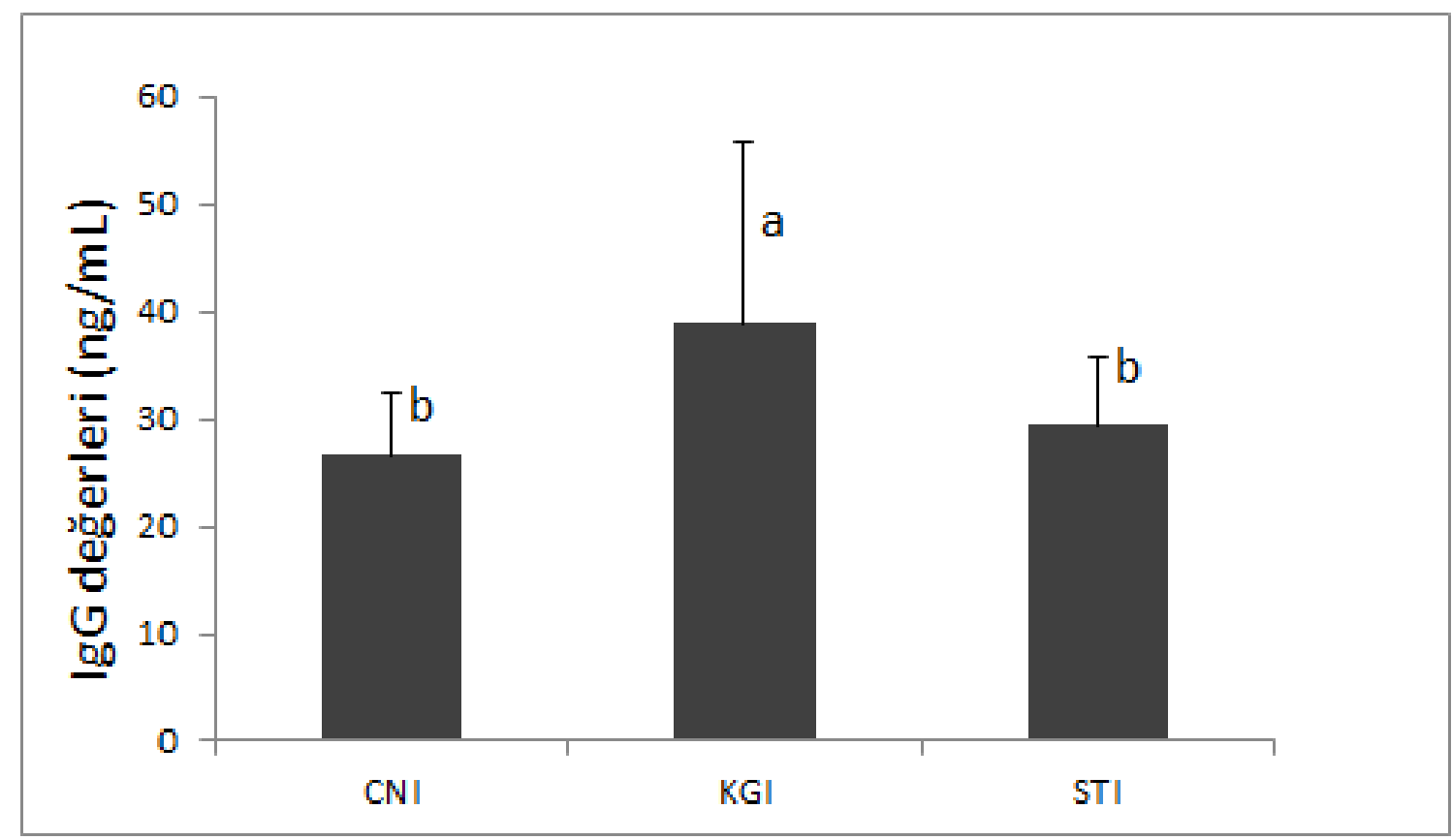

a,b,c Different letters indicate results were statistically different $(\mathrm{P}<0.05)$

Figure 2. IgG values of CNI, KGI and STI groups

In CNI, KGI and STI samples, IL-4 values were 84.00, 40.28 and $53.28 \mathrm{pg} / \mathrm{mL}$, respectively; there was a significant difference between all samples ( $\mathrm{P}<0.05$ ) (Figure 3$)$. Results indicated authentic kefir prepared from kefir grains lowered IL-4 levels significantly better than starter culture kefir.

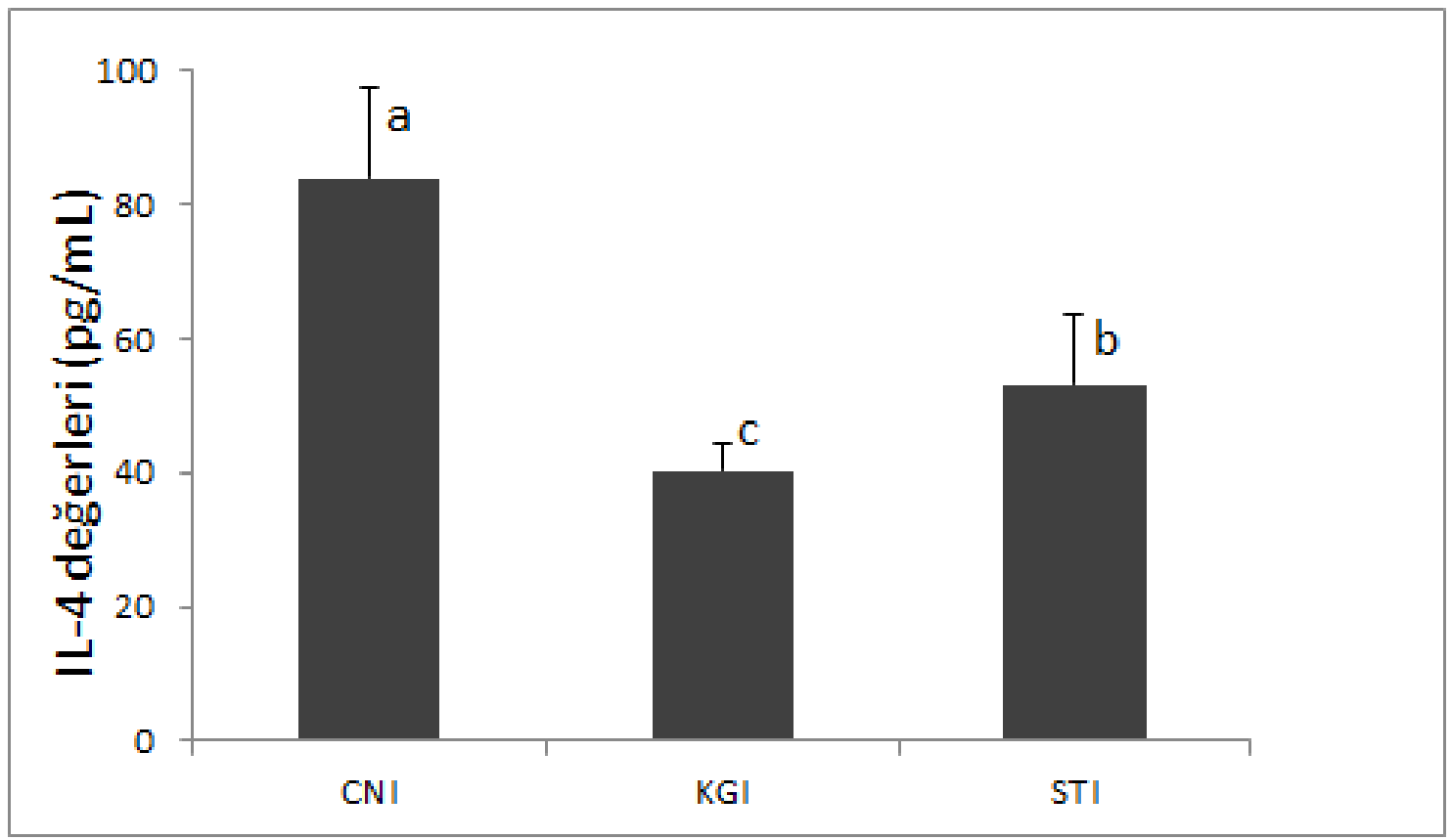

a,b,c Different letters indicate results were statistically different $(\mathrm{P}<0.05)$

Figure 3. IL-4 values of CNI, KGI and STI groups 
The IL-10 values were significantly higher in the KGI group than those in CNI and STI groups (P $<0.05$ ). In CNI, KGI and STI samples, IL-10 values were 110.98; 175.91 and $134.77 \mathrm{pg} / \mathrm{mL}$, respectively (Figure 4).

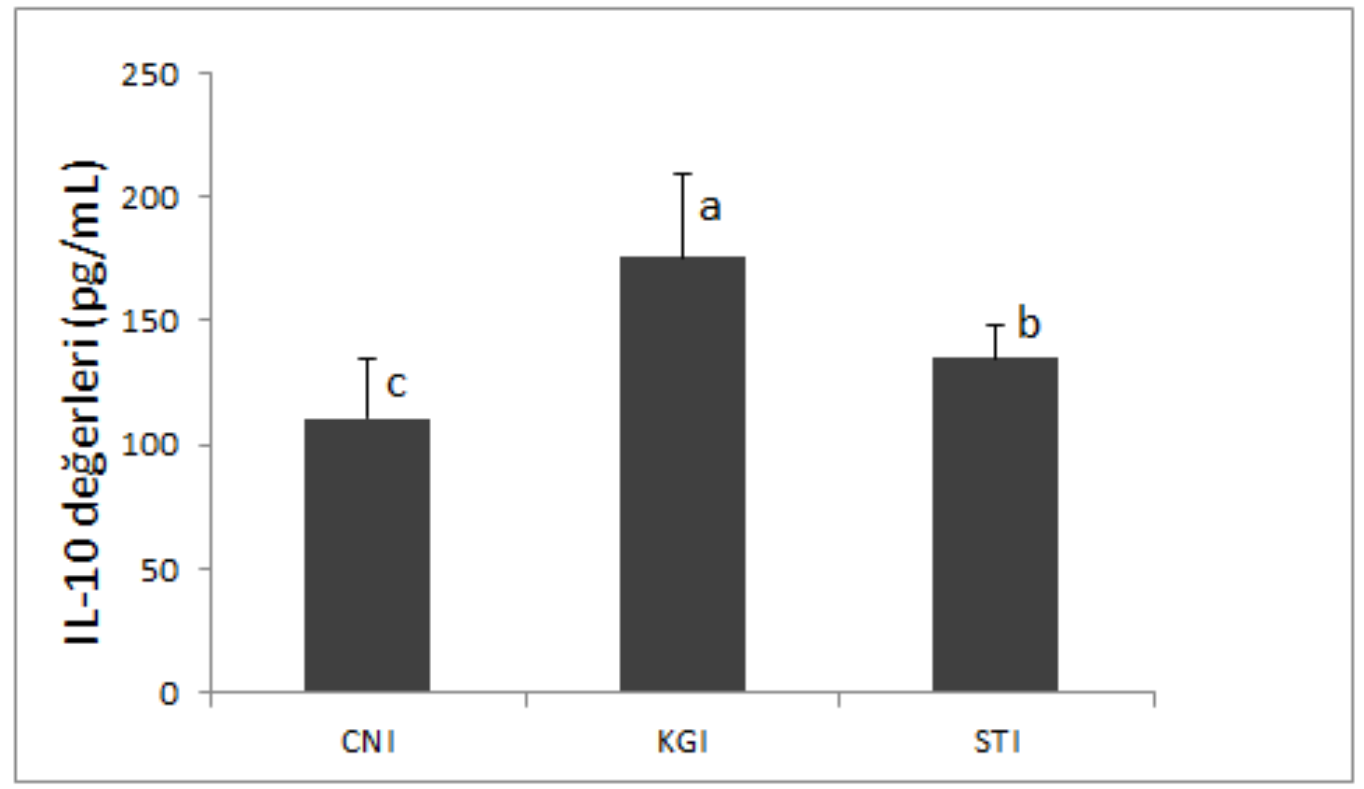

${ }^{a, b, c}$ Different letters indicate results were statistically different $(\mathrm{P}<0.05)$

Figure 4. IL-10 values of CNI, KGI and STI groups

In CNI, KGI and STI samples, IL-12 values were 53.90, 22.93 and $24.75 \mathrm{pg} / \mathrm{mL}$, respectively (Figure 5). All groups were significantly different $(\mathrm{P}<0.05)$.

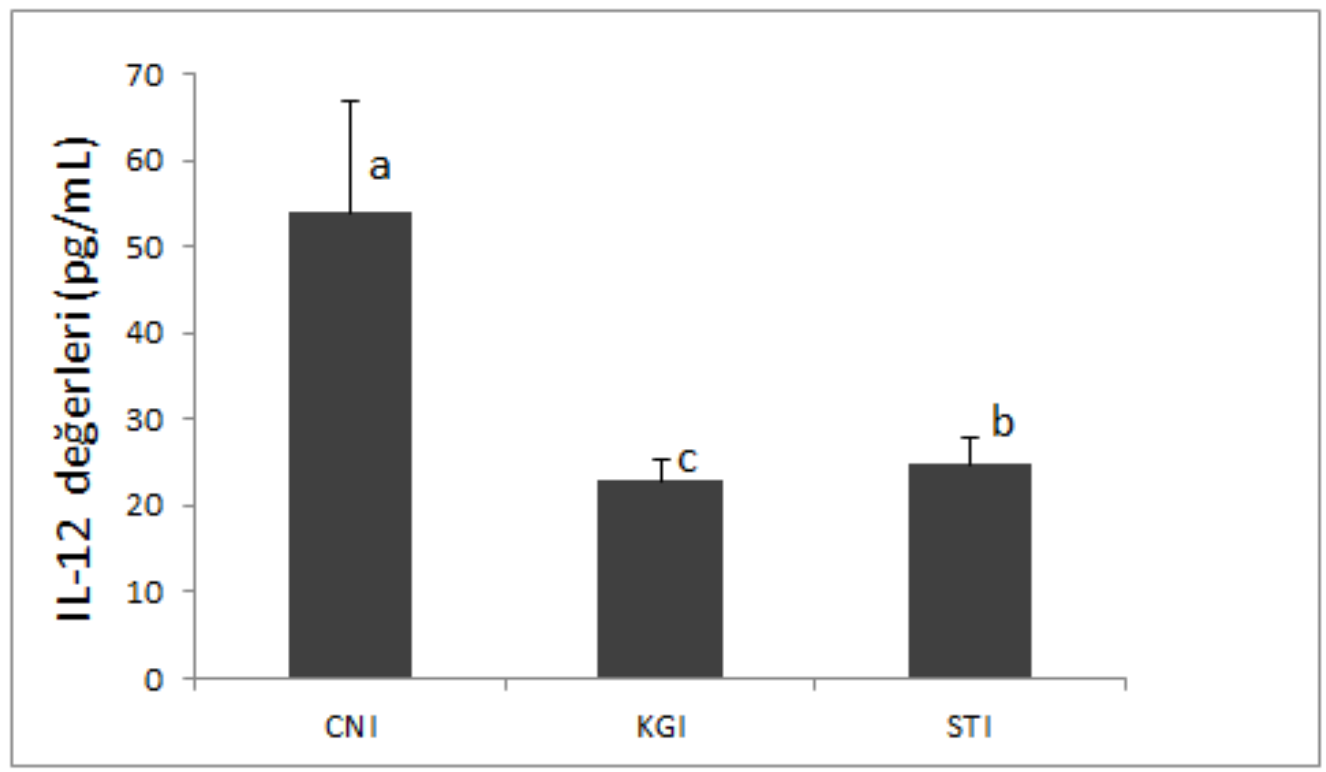

${ }^{a, b, c}$ Different letters indicate results were statistically different $(\mathrm{P}<0.05)$

Figure 5. IL-12 values of CNI, KGI and STI groups 
In CNI, KGI and STI samples, TLR-4 values were $0.53,0.43$ and $1.37 \mathrm{ng} / \mathrm{mL}$, respectively (Figure $6)$. It was determined that there was a significant difference in all samples $(\mathrm{P}<0.05)$.

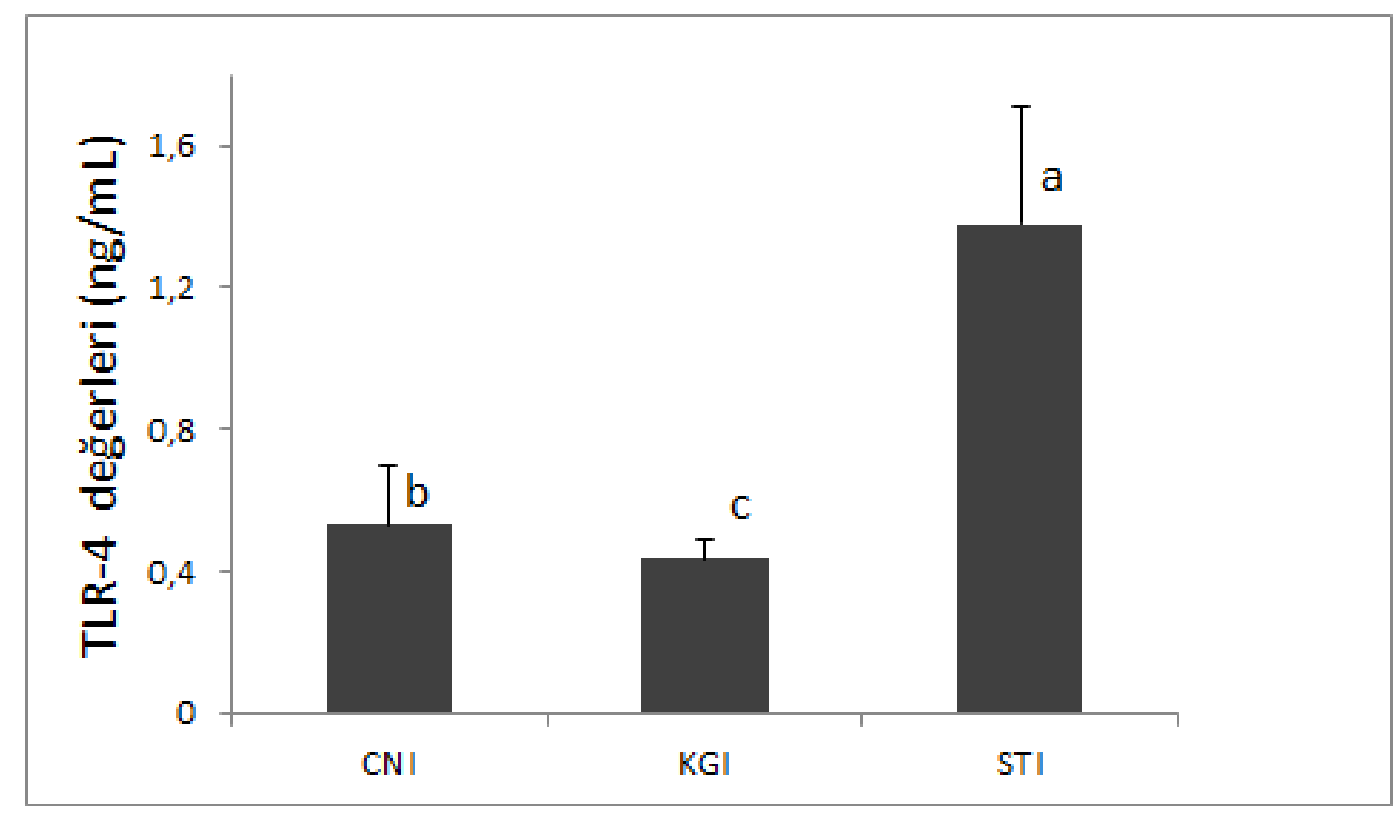

${ }^{a, b, c}$ Different letters indicate results were statistically different $(\mathrm{P}<0.05)$

Figure 6. TLR-4 values of CNI, KGI and STI groups

\section{DISCUSSION}

In a previous study conducted on L. acidophilus, L. reuteri and L. casei, IgA values increased in immunosuppressed mice with administration of these lactic acid bacteria [32]. In a similar study, the number of IgA levels were significantly increased after 7 days of feeding kefir compared to control [27]. With B. lactis and L. acidophilus consumption, an increase in serum IgA levels was observed compared to the control group [33]. It also was observed that there was an increase in the number of IgA cells in the lamina propria at the end of the 7th day of oral administration of kefiran to Balb/c mice [34]. Carasi et al. [26] found an increase in IgA levels in the feces of mice treated with probiotic microorganisms. The research findings of the present study are in agreement with other studies in that probiotics promote IgA production. In the present study, authentic kefir made from kefir grains significantly increased IgA over the control whereas the starter culture kefir caused slightly lower IgA levels compared to both the control and the kefir grain generated product.

In a study on probiotic administration to laboratory rats infected with Salmonella enteritidis, it was observed that IgA antibody secretion was significantly increased in the probiotic-fed mice [28]. In the present study, $\operatorname{IgA}$ levels significantly increased in KGI samples.

In the previously mentioned study on feeding L. acidophilus, L. reuteri and L. casei, $\operatorname{IgG}$ levels increased in immunosuppressed mice when fed the probiotics [32]. In a similar study, after kefir administration, a significant increase in IgG levels was observed on the 5th and 7th day as compared to control mice [27]. In yet another study, healthy human adults who consumed B. lactis and L. acidophilus, had an increase in serum IgG levels as compared to the control group [33]. In 
the present study, IgG levels were significantly higher in mice fed authentic kefir made from kefir grains compared to both the control and IgG levels in mice fed starter culture prepared kefir.

IL-10 promotes the balance between the function of cells that secrete pro-inflammatory cytokines and the function of cells that secrete anti-inflammatory cytokines [36]. In the present study, IL-10 levels significantly increased in KGI samples over both the STI and CNI samples. In a similar study, after kefir administration, IL-4 and IL-10 increased markedly in all periods, while IL-6 and IFN increased on days 2 and 5, respectively [27]. It was determined that with $L$. kefiranofaciens administration, there was an increase in IL-10 level in mice [37]. Generally, probiotics increase the production of intestinal anti-inflammatory cytokines such as interleukin-10 (IL-10) and TGF (Transforming Growth Factor)-beta, while reducing the production of proinflammatory cytokines such as IL-8 $[38,39]$. While it was observed that there was an increase in IgA levels in the feces of mice treated with probiotic microorganisms, there were significant decreases in the amounts of IL-23, IFN- $\gamma$, and IL-6, IL-10 levels with a decrease in the expression of proinflammatory mediators in the lymph node nodules [26]. Again, in a similar study, it was determined that on day 7 of kefir ingestion, IL-10 increased in the intestinal mucosa of the animals, and modulation of intestinal immunity provided the control of the intestinal homeostasis of macrophages [30]. Results of the present study support that authentic kefir produced using kefir grains causes greater IL-10 production than kefir produced from starter cultures.

It has been reported that the lower IL-12 levels may facilitate the control of inflammation. In the present study, the IL-12 levels of the KGI group were significantly lower than the CNI group. Concurrently, an increase in IL-10 was noted in the KGI group. These results may increase the secretory IgA levels, making the immunological response more effective. The interaction between IL-12 and IFN- $\gamma$ is necessary for effective immune responses against a large number of pathogens including intracellular bacteria such as mycobacteria. Previous studies using recombinant bovine IL-12 cells cloned in vitro and expressed were found to have IFN- $\gamma$-inducing activity [40]. The combination of IL-12 and IL-2 may help to increase IFN- $\gamma$ expression in the pulmonary tissue, but does not reduce colony burden in the pulmonary tissue or increase the survival rate of the mouse [41]. In addition, IL-10 inhibits IL-12 release from active macrophages and dendritic cells. It was also observed that IL-2, IL-6 and IFN-y production were significantly increased in probiotic-fed mice, while no significant change was observed in IL-4 levels [28]. Results of a previous study on rats fed B. breve and L. rhamnosus, indicated a decrease in IL-4 levels [35]. However, IL-2, IL4, IL-6 and IFN-y were not measured in the present study.

Toll-like receptor 4 (TLR-4) is found in tissues targeted for insulin activities. Probiotic consumption increases the number of Bifidobacteria present in the intestine causes increased expression of adhesion proteins which in turn attenuates intestinal permeability and weakens the activation of TLR-4 by bacterial lipopolysaccharide [42,43]. In the present study, higher Bifidobacterium spp. content was provided in authentic kefir produced by kefir grains and therefore, a more effective decrease in activation was observed at the TLR-4 level of the KGI group.

\section{CONCLUSION}


Nutritional habits have an important effect on the immune system. Recently studies have increased the understanding of the intestinal microbiota and intestinal health. Concurrently, there is an interaction between the consumption of probiotic microorganisms and the immune response. The probiotic effects of fermented dairy products arise not only from microorganisms but also from metabolites produced during fermentation. This study has determined that authentic kefir produced from kefir grains has a greater ability to modulate immunological responses compared to kefir produced by limited starter cultures as is commonly done for commercial kefir. It was found that secretory IgA and IgG levels were higher in mice fed with authentic kefir grain-generated kefir as compared to control and those fed with starter culture-generated kefir. In addition, the humoral immune system is higher in mice fed with authentic kefir grain-generated kefir. Authentic kefir appears to stimulate a more effective defensive mechanism in blood and in the lumen of the mucosal organs such as the gastrointestinal tract and respiratory tract.

This study has shown that under in vivo conditions, the microbiota of authentic kefir produced by natural kefir grain causes enhanced immunomodulator properties as compared to kefir produced using starter culture as is typical in commercial kefir.

List of Abbreviations: B, Bifidobacterium; CNI, control group; ELISA, Enzyme Linked ImmunoSorbent Assay; IFN, interferon; IG, Immunoglobulin; IL, interleukin; K, Kluyveromyces; KGI, the kefir produced using kefir grains; L, Lactobacillus; LAB, lactic acid bacteria; PBS, phosphate buffered saline; S, Saccharomyces; STI, the kefir produced using starter culture; TGF, Transforming Growth Factor; TLR, Toll Like Receptor.

Author Contributions: ZBGS, TKT and FD designed the research; FD, ZBGS and TKT performed the research; FD and TKT prepared the kefir samples and feed animals. FD, ZBGS and TKT analyzed the data; FD, ZBGS and TKT prepared the manuscript, figures, references.

Competing Interests: There are no conflicts of interest to declare.

Acknowledgments and Funding: This research was supported by Scientific Research Projects (Project No: 4679-YL2-16) of Suleyman Demirel University (Isparta,Turkey). We thank to Dr. Annel K. Greene for her valuable review of the manuscript and Danem Co. (Technopark, Suleyman Demirel University, Isparta) for providing natural kefir grains.

\section{REFERENCES:}

1. Farnworth ER, Mainville I: Kefir-A fermented milk product. In Handbook of Fermented Functional Foods. Edited by Farnworth E.R. Boca Raton, FL; 2008: 77-111.

2. Guzel-Seydim ZB, Kok-Tas T, Greene AK: Review: functional properties of kefir. Critical Reviews in Food Science and Nutrition 2010, 51: 261-268.

3. Rea MC, Lennartsson T, Dillon P, Drinan FD, Reville WJ, Heapes M, Cogan TM: Irish kefir-like grains: their structure, microbial composition and fermentation kinetics. Journal of Applied Bacteriology 1996, 81:83-94. 
4. Kok-Tas T, Ekinci Y, Guzel-Seydim ZB: Identification of Microbial Flora in Kefir Grains Produced in Turkey Using PCR. International Journal of Dairy Technology 2012, 65(1):126-131.

5. Pintado ME, Da Silva JA, Fernandes PB, Malcata FX, Hogg TA: Microbiological and rheological studies on Portuguese kefir grains. International Journal of Food Science Technology 1996, 31:15-26.

6. Wang SY, Chen HC, Liu JR, Lin YC, Chen MJ: Identification of yeasts and evaluation of their distribution in Taiwanese kefir and viili starters. Journal of Dairy Science 2008, 91: 3798-3805.

7. Hsieh HH, Wang SY, Chen TL, Huang YL, Chen MJ: Effects of cow's and goat's milk as fermentation media on the microbial ecology of sugary kefir grains. International Journal of Food Microbiology 2012, 157: 73-81.

8. Kim DH, Kang IB, Jeong D, Kim H, Kim HS, Lee SK, Song KY, et al.: Development of rapid and highly specific TaqMan probe-based real-time PCR assay for the identification and enumeration of Lactobacillus kefiri in kefir milk, International Dairy Journal 2016, 61:18-21.

9. Zhou J, Liu X, Jiang H, Dong M: Analysis of the microflora in Tibetan kefir grains using denaturing gradient gel electrophoresis. Food Microbiology 2009, 26(8): 770-775.

10. Garbers I, Britz T, Witthuhn R: PCR-based denaturing gradient gel electrophoretic typification and identification of the microbial consortium present in kefir grains. World Journal of Microbiology and Biotechnology 2004, 20: 687-693.

11. Guzel-Seydim ZB, Seydim AC, Greene AK, Tas T: Determination of antimutagenic properties of some fermented milks including changes in the total fatty acid profiles including CLA. International Journal of Dairy Technology 2006, 59 (3): 209-215.

12. Maalouf K, Baydoun E, Rizk S: Kefir induces cell-cycle arrest and apoptosis in HTLV1-negative malignant T-lymphocytes. Cancer Management and Research 2011, 3: 39-47.

13. Liu JR, Wang SY, Chen MJ, Chen HL, Yueh PY, Lin CW: Hypocholesterolaemic effects of milk kefir and soya milk kefirin cholesterol fed hamsters. British Journal of Nutrition 2006, 95: 939-946.

14. Furuno T, Nakanishi M: Kefiran suppresses antigen-induced mast cell activation. Biological and Pharmaceutical Bulletin 2012, 35(2):178-183.

15. De Angelis-Pereira MC, Barcelos MFP, Sousa MSB, Pereira JAR: Effects of the kefir and banana pulp and skin flours on hypercholesterolemic rats. Acta Cirurgica Brasileira 2013, 28(7): 481-486.

16. Teruya K, Yamashita M, Tominaga R, Nagira T, Shim SY, Katakura Y, Tokumaru S, et al.: Fermented milk, Kefram-Kefir enhances glucose uptake into insülin-responsive muscle cells. Cytotechnology 2002, 40(1-3): 107-116.

17. Erdogan FS: Dogal kefir danesi ve starter kefir kulturu kullanılarak uretilen kefirin in vivo fekal probiyotik mikroorganizmaların belirlenmesi. Yuksek Lisans Tezi: Suleyman Demirel Universitesi, Fen Bilimleri Enstitusu; 2016. 
18. De Vrese M, Keller B, Barth CA: Enhancement of intestinal hydrolysis of lactose by microbial $\beta$-galactosidase (EC 3.2.1.23) of kefir. British Journal of Nutrition 1992, 67(1):67-75.

19. Quiros A, Hernazdez-Ledesna B, Ramos M, Amigo L: Converting enzyme inhibitory activity of peptides I. Derived from caprine kefir. Journal of Dairy Science 2005, 88(10):3480-3487.

20. Zacconi C, Parisi MG, Sarra PG, Dallavalle P, Bottazzi V: Competitive exclusion of Salmonella kedougou in kefir fed chicks. Microbiologie, Aliments, Nutrition 1995, 12: 387-390.

21. Ulas-Kadıglu B: Probiyotik sut urunu olarak kefirin saglıklı beslenmedeki yeri. The Journal of Academic Social Science 2017, 60(5): 135-145.

22. Guzel-Seydim ZB, Dibekci M, Cagdas E, Seydim AC: Effect of kefir on Fusobacterium nucleatum in potentially preventing intestinal cancer. Functional Foods in Health and Disease 2016, 6(7):469-477.

23. Murofushi M, Shiomi M, Aibara K: Effect of orally administered polysaccharide from kefir grain on delayed-type hypersensitivity and tumor growth in mice. Japanese Journal of Medical Science and Biology 1983, 36(1): 49-53.

24. LeBlanc AM, Matar C, Theriault C, Pertigon G: Effects of milk fermented by Lactobacillus helveticus R389 on immune cells associated to mammary glands in normal and a breast cancer model. Immunobiology 2005, 210: 349-358.

25. Ashraf R, Shah NP: Immune system stimulation by probiotic microorganisms. Critical Reviews in Food Science and Nutrition 2014, 54(7): 938-956.

26. Carasi P, Racedo SM, Jacquot C, Romanin DE, Serradell MA, Urdaci MC: Impact of kefir derived Lactobacillus kefiri on the mucosal immune response and gut microbiota. Hindawi Publishing Corporation Journal of Immunology Research 2015, 12.

27. Vinderola G, Perdigon G, Duarte J, Farnworth E, Matar C: Effects of the oral administration of the products derived from milk fermentation by kefir microflora on immune stimulation. Journal of Dairy Research 2006, 73:472-479.

28. Jain S, Yadav H, Sinha PR, Naito Y, Marotta F: Dahi containing probiotic Lactobacillus acidophilus and Lactobacillus casei has a protective effect aganist Salmonella enteritidis infection in mice. International Journal of Immunopathology and Pharmacology 2008, 21(4).

29. Hong WS, Chen YP, Dai TY, Huang IN, Chen MJ: Effect of heat-inactivated kefirisolated Lactobacillus kefiranofaciens $\mathrm{M} 1$ on preventing an allergic airway response in mice. Journal of Agricultural and Food Chemistry 2011, 59(16): 9022-9031.

30. Maciel FR, Punaro GR, Rodriguez AM, Bogsan CSB, Rogero MM, Oliveira MN, Mouro MG, et al.: Immunomodulation and nitric oxide restoration by a probiotic and its activity in gut and peritoneal macrophages in diabetic rats. Clinical Nutrition 2016, 35: 10661072.

31. Adiloglu AK, Gonulates N, Isler M, Senol A: Kefir tuketiminin insan bagisiklik sistemi uzerine etkileri: Bir sitokin calismasi. Mikrobiyoloji Bulteni 2013, 47(2):273-281. 
32. Wagner RD, Pierson C, Warner T, Dohnalek M, Farmer J, Roberts L, Hilty M, et al.: Biotherapeutic effects of probiotic bacteria on candidiasis in immunodeficient mice. Infection and Immunity 1997, 65:4165-4172.

33. Paineau D, Carcano D, Leyer G, Darquy S, Alyanakian MA, Simoneau G, Bergmann JF, et al.: Effects of seven potential probiotic strains on specific immune responses in healthy adults: A double-blind, randomized, controlled trial. FEMS Immunology and Medical Microbiology 2008, 53:107-113.

34. Medrano M, Racedo SM, Rolny IS, Abraham AG, Perez PF: Oral administration of kefiran induces changes in the balance of immune cells in a murine model. Journal of Agricultural and Food Chemistry 2011, 59: 5299-5304.

35. Hougee S, Vriesema AJM, Wijering SC, Knippels LMJ, Folkerts G, Nijkamp FP, Knol $\mathrm{J}$, et al.: Oral treatment with probiotics reduces allergic symptoms in ovalbuminsensitized mice: A bacterial strain comparative study. Int. Arch. Allergy Immunol.2010, 151:107-117.

36. Abbas AK, Lichtman AH, Pillai S: Temel Immunoloji Immun Sistemin Islevleri ve Bozukluklari 4. Baski, Cev. Camcioglu, Y., Deniz, G., Guneş Tıp Kitabevleri, 320s, Ankara; 2015.

37. Chen YP, Hsiao PJ, Hong WS, Dai TY, Chen MJ: Lactobacillus kefiranofaciens M1 isolated from milk kefir grains ameliorates experimental colitis in vitro and in vivo. Journal of Dairy Science 2012, 95: 63-74.

38. Maassen CBM, Holten-Neelen C, Balk F, Bak-Glashouwer MJH, Leer RJ, Laman JD, Boersma WJA, et al.: Strain-dependent induction of cytokine profiles in the gut by orally administered Lactobacillus strains. Vaccine 2000, 18: 2613-2623.

39. Yesilova Y, Sula B, Yavuz E, Ucmak D. Probiyotikler. Kartal Egitim ve Arastirma Hastanesi Tip Dergisi 2010, 21(1): 49-56.

40. Hope JC, Kwong LS, Entrican G, Wattegedera S, Vordermeier HM, Sopp P, Howard CJ: Development of detection methods for ruminant interleukin (IL)-12. Journal of Immunological Methods 2002, 266: 117- 126.

41. Zhang CR, Lin JC, Xu WM, Li M, Ye HS, Cui WL, Lin Q: Interleukin-12 and interleukin-2 alone or in combination against the infection in invasive pulmonary aspergillosis mouse model. Mycoses 2013, 56:117-122.

42. Gomes AC, Bueno AA, Souza RGM, Mota JF: Gut microbiota, probiotics and diabetes. Nutrition Journal 2014, 13(60).

43. Bubnov RV, Spivak MY, Lazarenko LM, Bomba A, Boyko NV: Probiotics and immunity: provisional role for personalized diets and disease prevention. The EPMA Journal 2015, 6(14). 